\title{
The Impact of Enterprise Risk Management on Firm Value: Empirical Evidence from Romanian Non-Financial Firms
}

\author{
Sorin Gabriel Anton
}

\author{
Alexandru Ioan Cuza University of Iasi \\ Carol I Avenue, No. 22, 700505, Iasi, Romania \\ E-mail.sorin.anton@uaic.ro
}

cross $^{\text {ref }}$ http://dx.doi.org/10.5755/j01.ee.29.2.16426

\begin{abstract}
Enterprise risk management (ERM) represents a significant change in the way firms manage risks. In the last years, an increasing number of non-financial firms from emerging economies started to implement a holistic framework for risk management. However, little is known about the impact of ERM adoption on firm value in emerging markets. The aim of the paper is to investigate the effects of ERM implementation on the firm value in different economic environments. The empirical research of this study is conducted using econometric software EViews and panel data techniques. Employing a sample of Romanian listed firms for the pre-crisis period (2001-2007), it has been found that ERM adoption is associated with higher firm values, indicated by a Tobin's $Q$ premium of roughly $46.5 \%$. Also, it has been found a positive and statistically significant relationship between size and leverage, on one hand, and firm value, on the other hand. Extending the sample over the financial crisis period (2001-2011), it has been found that ERM does not affect firm value in any significant manner. These findings lend support for the recent pressure on firms to adopt more integrated and comprehensive risk management systems.
\end{abstract}

Keywords: Enterprise Risk Management; Firm Value; Emerging Market; Non-Financial Firms; Financial Crisis.

\section{Introduction}

The importance of risk management has increased significantly in the last years. Rating agencies, public authorities, regulators, and stock exchanges have recognized the need for risk management and have imposed several requirements in order to enhance risk management practices within public firms. In the extant literature, there is a growing consensus among practitioners and academics alike about the fact that Enterprise Risk Management (ERM) represents the fundamental paradigm for managing the portfolio of risks confronting enterprises. According to Nocco \& Stulz (2006), $\mathrm{ERM}$ is a process that identifies, assesses, and manages individual risks (e.g., currency risk, interest rate risk, reputational risk, and legal risk) within a coordinated and strategic framework. ERM can be seen as taking a portfolio view of all risks faced by a firm (Bromiley et al., 2015), whether it is risk related to corporate governance, supply chains, distribution systems, IT, or human resource. The goal of ERM is to gain "a systematic understanding of the interdependencies and correlations among risks" (McShane et al., 2011). Hoyt and Liebenberg have synthesized the ways ERM helps increase the value of firms, namely by "reducing the volatility of their earnings and stock prices, reducing their costs of external capital, increasing their capital efficiency, and creating synergies among their different risk management activities" (Hoyt \& Liebenberg, 2015, p. 41).

In the last two decades, Romanian firms have changed the way they manage financial risks. More and more public firms started to shift from a traditional silo-based risk management approach to a more comprehensive one, namely Enterprise Risk Management. However, little is known about the value relevance of ERM for non-financial firms.

The goal of the study is to assess the effects of ERM implementation on the firm value. Prior studies (Hoyt \& Liebenberg, 2011; McShane et al., 2011; Bertinetti et al., 2013) have offered mixed and limited findings and have focused mainly on financial firms (insurance companies), as these have been leaders in implementing ERM. Only a few studies used a sample of financial firms from emerging economies, among them, Li et al. (2014) and Li et al. (2016).

The study employs a sample of 65 non-financial Romanian firms that are listed on the Bucharest Stock Exchange (BSE) over the period 2001-2011. The results of the fixed-effects panel regression analysis for the pre-crisis period (2001-2007) suggest that ERM implementation is associated with a higher firm value. Extending the analysis over the financial crisis period (2001-2011), it has been found that ERM does not affect firm value in any significant manner.

The contribution of this paper to the existing literature is threefold. To the best of author's knowledge, this is the first study to analyze the effects of risk management practices on the firm value on a sample of non-financial firms from emerging economies. Secondly, the paper contributes to the extant literature through the expanding of knowledge on the relationship between risk management and firm value on a sample of non-financial firms, as most of the previous papers focused on insurance companies or on mixed samples. Thirdly, the paper extends the existing knowledge by analyzing a sample of non-financial firms over the precrisis period and also during the latest global financial crisis in order to test the effects of ERM on firm value in various economic conditions. 
The remainder of the present paper is organized into four parts. Section 2 reviews the extant literature regarding the effects of risk management on firm value. In section 3, an explanation of data and the methodology employed in the paper is provided. Section 4 presents and discusses the key results of the study. Section 5 concludes the paper, highlights some limits of the research and discusses avenues for further research.

\section{Literature Review}

According to Modigliani and Miller's financial irrelevance theorem, a firm would not engage in hedging activities, since these activities add no value to the firm (Modigliani \& Miller, 1958). Starting 80's, the role of risk management has been reconsidered and numerous theoretical papers have argued that, in the presence of capital market imperfections, corporate risk management constitutes a means to increase shareholders' value. Important theoretical contributions in this field have been those of Smith \& Stulz (1985), Bessembinder (1991), Nance et al. (1993), Froot \& Stein (1998), Noco \& Stulz (2006), and Aretz et al. (2007).

In the extant literature, there are two main streams of research focused on the risk management effects on firm value. Firstly, in the traditional risk management or silobased approach, numerous papers have studied the effects of hedging with financial derivatives on firm value. Allayannis \& Weston (2001), Nelson et al. (2005), Carter et al. (2006), Bartram et al. (2011), and Panaretou (2014), among others, found a positive relation between risk management with financial derivatives and firm value. However, Guay \& Kothari (2003), Jin \& Jorion (2006), Fauver \& Naranjo (2010), Allayannis et al. (2012), and Belghitar et al. (2013) found either no relation or only a conditional positive or negative relation between derivatives usage and firm value.

The second stream of literature has shifted the focus from instruments used for financial risk management (e.g., financial derivatives) to the effects of ERM on firm value. In the ERM framework, the firms should identify, measure all of its risk exposures (including operational and competitive risks) and manage them in an integrated, continuous, and broadly focused approach (Harrington et al., 2002). Most of the studies focused on financial firms from the U.S. and Europe and their findings are still mixed and limited (McShane et al., 2011; Farrell \& Gallagher, 2015; Bromiley et al., 2015). One reason behind these mixed results is that the extant studies employed different samples of firms (financial and non-financial), different time spans, and various proxies for ERM implementation. Hoyt and Liebenberg (2011), Bertinetti et al. (2013), Baxter et al. (2013), Eckles et al. (2014), and Farrell and Gallagher (2015) showed that ERM influence positively firm performance measured in market value or in accounting indicators. Using a sample of 117 publicly traded U.S. insurance firms over the period between 1998 and 2005, Hoyt \& Leibenberg (2011) found that ERM has a positive effect on firm value and the valuation premium is large (20\%). Bertinetti et al. (2013) used a sample of 200 large European firms to assess the influence of ERM on firm value. The sample comprised publicly-traded firms from 17 different industries, including financial industry. Their results confirmed the findings of previously mentioned studies. Grace et al. (2015) demonstrated that U.S. insurers with more ERM initiatives implemented (e.g., dedicated risk manager appointment) exhibit higher firm value. Employing a sample of 354 publicly-traded insurance companies in the U.S.A. over the period between 1990 and 2008, Eckles et al. (2014) highlighted that ERM adoption reduces firm risk and also it increases accounting performance for a given unit of risk.

Other studies (Beasley et al., 2008; Gordon et al., 2009; Pagach \& Warr 2010; McShane et al., 2011; Milos Sprcic et al., 2016) found no support for value creation of ERM or the positive effects of an ERM framework depends on firmspecific factors. Beasley et al. (2008) found an insignificant market reaction when financial firms announce the appointment of a Chief Risk Officer (a proxy for ERM adoption). Using a sample of U.S. firms for the fiscal year 2005, Gordon et al. (2009) found that the positive influence of ERM on firm performance (measured as one-year excess market return) is contingent on how well ERM implementation matches firm-specific factors. Employing Standard \& Poor's ERM rating for insurance companies, McShane et al. (2011) argued that firm value is positively associated with increased level of traditional risk management and negatively with higher ERM rating.

\section{Data and Methodology}

This study discusses the relationship between ERM and firm value of the sampling of 65 non-financial Romanian firms listed on the Bucharest Stock Exchange (BSE) over the period 2001-2011. A sample of publicly traded firms has been chosen in order to exploit their market-based measures of values and their greater public disclosures of risk management activity.

The data for the empirical analyzes comes from different sources: information on firms' market value has been obtained from the BSE website; data for financial variables have been hand collected from annual reports; data concerning risk management activity of public firms have been hand collected from annual reports over an eleven-year sample period (2001-2011). The time period of the analysis ends in 2011 due to reporting reasons. Over the period 2001-2011, the Romania listed firms had to report financial data according to the Romanian Accounting Standards. From 2012, listed firms in Romania were expected to use the International Financial Reporting Standards (IFRS) and, therefore, financial data are less comparable with those reported for the period 2001-2011.

Outliers have been eliminated by winsorizing observations in the top and bottom 1 percentile as well as those observations where variable values exceed more than 5 standard deviations from the median.

In order to evaluate the effects of hedging on the firm value the following equation is estimated:

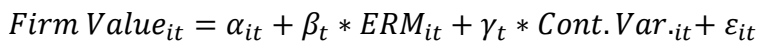

Where: Firm Value it represents the natural logarithmic of Tobin's $\mathrm{Q}$, for firm $i$ at time $t$ : ERM $_{\mathrm{it}}$ is a dummy variable indicating the implementation of ERM framework by the 
firm $i$ at time $t$; Cont. Var. $_{\text {it }}$ represents the control variables for firm $i$ at time $t ; \varepsilon_{\text {it }}$ is the error term.

A fixed-effects panel regression analysis has been carried out in order to control for unobservable firm characteristics that may influence firm value. All the estimations are made by econometric software EViews.

Following the existing literature, firm value is measured using Tobin's Q. This variable is computed by dividing market value of a firm by the replacement value of its assets, where market value is given by the following relation:

Market value $_{i t}=$ total assets $_{i t}-$ book value of equity ${ }_{i t}+$ market value of equity it $_{\text {. }}$

The log transformation of Tobin's Q accounts for the skewed distribution of this variable and also has the advantage of allowing interpretations of regression coefficients in percentage terms. Moreover, most of the empirical studies on the value relevance of risk management use Tobin's Q to proxy for firm value.

One important issue in studying the relationship between ERM and firm value is to find a suitable proxy for the ERM implementation. Most of the previous papers (Beasley et al., 2008; Pagach \& Warr, 2010; Hoyt \& Liebenberg, 2011; Bertinetti et al., 2013) employ the hiring of a CRO as a proxy for ERM implementation. In order to overcome the drawbacks of this proxy, Gordon et al. (2009) elaborate an ERM index to catch various aspects of firm characteristics and environment. McShane et al. (2011) employ Standard \& Poor's rating for ERM implementation within the insurance companies.

As independent variable of interest, a dummy variable for ERM implementation is used. ERM takes value 1 if firms implement an ERM system and 0 otherwise. Consistent with previous studies (e.g., Hoyt \& Liebenberg, 2011; Gordon et al., 2009), firms were identified as employing an ERM system based on a search of the following key terms and their acronyms in the annual reports: "enterprise risk management", "strategic risk management", "corporate risk management", "consolidated risk management", "holistic risk management", "integrated risk management", "risk management committee", "risk committee", and "chief risk officer" (CRO). The first six terms are synonyms for ERM, while the last three are proxies for ERM implementation (Hoyt \& Liebenberg, 2011; Lundqvist, 2015).

The following control variables are employed in the models: the size of the firm (total assets or turnover), the ability to access financial market (FINCONS), the leverage (LEVERAGE), the liquidity (QUICK), the profitability (ROA), and the investment opportunities (INVOPP). The choice of many independent variables is consistent with the extant literature focused on firms from developed economies (Allayannis \& Weston, 2001; Bertinetti et al., 2013). Table 1 provides the definitions of the variables used throughout the panel data analysis and the expected sign. All the variables are measured at the end of each fiscal year.

Table 1

Independent and Control Variables Employed in the Panel Data Analysis

\begin{tabular}{|l|l|l|l|}
\hline \multicolumn{1}{|c|}{ Variable name } & \multicolumn{1}{|c|}{ Symbol } & \multicolumn{1}{c|}{ Definition } \\
\hline ERM dummy & ERM & $\begin{array}{l}\text { Equals } 1 \text { if the firm implements an ERM system and } 0 \\
\text { otherwise. }\end{array}$ & $\begin{array}{l}\text { Total assets is a scale variable used to control for the firm's } \\
\text { size. The natural logarithm of firm's } i \text { total assets at time } t \text { is } \\
\text { used. }\end{array}$ \\
\hline Total assets & TA & $\begin{array}{l}\text { The total value of sales. It is computed as the natural logarithm } \\
\text { of firm's } i \text { total sales at time } t .\end{array}$ \\
\hline Turnover & TURNOVER & Long-term debt over total equity \\
\hline Leverage & LEVERAGE & Cash plus short-term investments divided by current liabilities & + \\
\hline Liquidity & QUICK & Ratio of gross profits to total assets of firm \\
\hline Profitability & ROA & Capital expenditures over total sales \\
\hline $\begin{array}{l}\text { Investment } \\
\text { opportunities }\end{array}$ & INVOPP & $\begin{array}{l}\text { The dividend dummy will take value 1 if the firm paid a } \\
\text { dividend in the current year and } 0 \text { otherwise. Obtained from } \\
\text { annual reports. }\end{array}$ \\
\hline $\begin{array}{l}\text { Access to financial } \\
\text { markets }\end{array}$ & FINCONS & + \\
\hline
\end{tabular}

Colquitt et al. (1999), Gordon et al. (2009), and Hoyt \& Liebenberg (2011) have highlighted that large firms are more likely to implement an ERM system than are small firms. In this paper, two alternative measures are used to control for size-related variation in Tobin's Q, namely total assets and turnover. A robustness test of the findings is conducted by replacing variable turnover with total assets in the estimations.

As already documented in many empirical papers explaining firm value, leverage can have a significant effect, positive or negative. On the one hand, greater leverage implies greater default risk and possible financial distress costs. On the other hand, a low level of leverage enhances firm value due to the fact that "it reduces free cash-flow which might otherwise have been invested by self-interested managers in sub-optimal projects" (Hoyt \& Liebenberg,
2011, p. 803). Therefore, there are no expectations regarding the sign of the relationship between leverage and firm value.

In order to control for financial liquidity, the quick ratio is employed in the models. Firms with higher liquidities have more possibilities to undertake profitable investments and thus to improve their performance. Therefore, a positive relationship between the financial liquidity and Tobin' $Q$ is expected.

Several papers have highlighted that more profitable firms had a higher value than otherwise identical less profitable firms (Allayannis \& Weston, 2001). Return on assets (ROA) is used to control for the effects of firm profitability on firm value. In the data panel analysis, a positive relation between ROA and firm value is expected. 
The existence of prospective investment opportunities can have significant effects on firm performance. Following the extant literature (Allayannis \& Weston, 2001), the ratio of capital expenditures to total sales is used as a proxy for investment opportunities (or growth opportunities). A positive relation between investment opportunities and firm value is expected.

In imperfect financial markets, financial constraints can affect the firm's value. Following Allayannis and Weston (2001), a dummy variable is included in the model in order to proxy for the ability to access financial markets. The dividend dummy will take value 1 if the firm paid a dividend in the current year, and 0 otherwise. The expected sign for this variable is controversial in the extant literature. On the one hand, paying dividends the firm is signaling that it has exhausted its growth opportunities. On the other hand, a disbursement of cash in the form of dividends reduces free cash flows available to managers for consumption and affects positively the firm value (Hoyt \& Liebenberg, 2011). Therefore, there is no expectation regarding the sign of the relationship between financial constraints and firm value.

\section{Empirical Results}

Table no 2 shows descriptive statistics for the full unbalanced panel dataset with 65 firms. The number of observations per time period varies due to missing observations, new stock listings, and delistings. The minimum number of observations by a firm in the sample is three. As a result of these restrictions, the final sample includes 475 firm-years observations over the period 20012011. In this particular sample, Tobin's Q displays a wide variation across firms over time, from 0.07 to 7.38. The analysis shows that an increasing number of Romanian public firms have implemented ERM programs. Also, $9.89 \%$ of all the firm-years have implemented ERM programs over the period between 2001 and 2011. This percentage is in line with values reported for other studies and reflects the early years when Romanian firms just started to implement an ERM framework.

Descriptive Statistics for Variables Employed in Analysis

Table 2

\begin{tabular}{|l|c|c|c|c|c|c|}
\hline Variable & Mean & Median & Max. & Min. & Std. Dev. & N \\
\hline TOBINQ & 0.97 & 0.78 & 7.38 & 0.07 & 0.84 & 475 \\
\hline ERM & 0.09 & 0.00 & 1.00 & 0.00 & 0.29 & 475 \\
\hline TURNOVER & 588363 & 82295 & 16750726 & 1174 & 1992439 & 475 \\
\hline TA & 848873 & 130541 & 33819554 & 13068 & 3343498 & 475 \\
\hline LEVERAGE & 17.04 & 1.66 & 255.64 & 0.00 & 41.37 & 475 \\
\hline QUICK & 0.80 & 0.13 & 9.82 & 0.00 & 1.66 & 475 \\
\hline ROA & 2.69 & 2.95 & 35.66 & -30.35 & 10.39 & 475 \\
\hline INVOPP & 0.03 & 0.00 & 0.24 & 0.00 & 0.05 & 475 \\
\hline FINCONS & 0.33 & 0.00 & 1.00 & 0.00 & 0.47 & 475 \\
\hline
\end{tabular}

First, the correlation across explanatory variables is tested and based on the results one of those variables proved to be (highly) correlated will be excluded from the empirical analysis in order to avoid possible multicollinearity problems in the regressions. Table 3 shows correlations among the dependent and independent variables. The results suggest a strong correlation between turnover and total assets. As a consequence, only one variable (turnover) is used as a proxy for firm size. As expected, a moderate correlation between the size of the firm (proxied by total assets or turnover) and the implementation of ERM has been found. Unexpectedly, the correlation between the explanatory variables and Tobin's $Q$ is weak. The low correlation coefficients between the independent variables suggest that multicollinearity is unlikely to be a problem in the panel data analysis.

Results from the Hausman test (not reported here, but available upon request) reveal that the fixed-effects models should be used. Table 4 shows the results of the estimations. First, in order to exclude the effect of the financial crisis, two models for the period 2001-2007 have been employed. The first model includes turnover, leverage, quick ratio, ROA, and investment opportunities as control variables. For robustness purposes, the second model adds a dummy variable (FINCONS), which excludes the effect of financial constraints on firm value.

Table 3

Correlation Matrix

\begin{tabular}{|l|c|c|c|c|c|c|c|c|c|}
\hline & $(\mathbf{1})$ & $\mathbf{( 2 )}$ & $\mathbf{( 3 )}$ & $\mathbf{( 4 )}$ & $\mathbf{( 5 )}$ & $\mathbf{( 6 )}$ & $\mathbf{( 7 )}$ & $\mathbf{( 8 )}$ & $\mathbf{( 9 )}$ \\
\hline (1) TOBINQ & 1.000 & & & & & & & & \\
\hline (2) ERM & -0.019 & 1.000 & & & & & & & \\
\hline (3) TURNOVER & 0.024 & 0.524 & 1.000 & & & & & & \\
\hline (4) TA & 0.019 & 0.495 & 0.947 & 1.000 & & & & & \\
\hline (5) LEVERAGE & 0.100 & -0.029 & 0.015 & 0.005 & 1.000 & & & & \\
\hline (6) QUICK & -0.068 & -0.048 & -0.053 & -0.035 & -0.151 & 1.000 & & & \\
\hline (7) ROA & 0.031 & 0.072 & 0.014 & 0.045 & -0.163 & 0.197 & 1.000 & & \\
\hline (8) INVOPP & 0.067 & 0.224 & 0.120 & 0.171 & 0.078 & 0.087 & -0.082 & 1.000 & \\
\hline (9) FINCONS & 0.024 & 0.155 & 0.087 & 0.117 & -0.187 & 0.079 & 0.436 & -0.007 & 1.000 \\
\hline
\end{tabular}


Employing a panel data model with fixed-effects, a positive and statistically significant relationship between ERM and firm value has been found (see table 4). Firms employing ERM are valued as more as $46.5 \%$ higher than other firms, after controlling for other factors. These findings are broadly in line with those obtained by Hoyt and Liebenberg (2011), Baxter et al. (2013), and Bertinetti et al. (2013) on different samples of firms from developed economies.

The Effect of ERM Adoption on Firm Value (2001-2007)

\begin{tabular}{|c|c|c|}
\hline Variables & $\mathbf{1}^{\text {st }}$ Model & $2^{\text {nd }}$ Model \\
\hline $\mathrm{C}$ & $\begin{array}{l}-5.193909 \\
(0.848283)\end{array}$ & $\begin{array}{l}-5.065441 \\
(0.861409)\end{array}$ \\
\hline ERM & $\begin{array}{l}0.469376^{* *} \\
(0.201733)\end{array}$ & $\begin{array}{l}0.464960 * * \\
(0.201919)\end{array}$ \\
\hline LOG(TURNOVER) & $\begin{array}{c}0.450618 * * * \\
(0.074383)\end{array}$ & $\begin{array}{c}0.442094 * * * \\
(0.075064)\end{array}$ \\
\hline LEVERAGE & $\begin{array}{l}0.002536 * * \\
(0.000982)\end{array}$ & $\begin{array}{c}0.002482 * * \\
(0.000985)\end{array}$ \\
\hline QUICK & $\begin{array}{c}-0.179739 * * * \\
(0.030859) \\
\end{array}$ & $\begin{array}{c}-0.178064^{* * * *} \\
(0.030938) \\
\end{array}$ \\
\hline ROA & $\begin{array}{l}-0.001399 \\
(0.004097)\end{array}$ & $\begin{array}{l}-0.000426 \\
(0.004248)\end{array}$ \\
\hline INVOPP & $\begin{array}{l}1.768352 \\
(1.705643)\end{array}$ & $\begin{array}{l}1.789761 \\
(1.706866)\end{array}$ \\
\hline FINCONS & - & $\begin{array}{l}-0.090538 \\
(0.103474)\end{array}$ \\
\hline R-squared & 0.61 & 0.61 \\
\hline Adjusted $\mathrm{R}^{2}$ & 0.51 & 0.51 \\
\hline Total panel (unbalanced) observations & 241 & 241 \\
\hline \multicolumn{3}{|c|}{$\begin{array}{l}\text { Standard error in parentheses } \\
* * * \mathrm{p}<0.01, * * \mathrm{p}<0.05, * \mathrm{p}<0.1\end{array}$} \\
\hline
\end{tabular}

Also a positive and statistically significant relationship between size and leverage, on one hand, and firm value, on the other hand, has been found. These results suggest that large firms are more likely to implement an ERM framework given the existence of large initial fixed start-up costs and scale economies. The relationship between liquidity (quick ratio) and firm value is negative and statistically significant in both models. The effect of the remainder explanatory variables on firm value is statistically insignificant.

In the second phase of the data panel analysis, the time span is extended to the 2001-2011 period in order to assess the effect of ERM on firm value during difficult economic conditions. The results of the two models are reported in
Table 5. Including in the analysis data for the financial crisis period, the results show that the effect of ERM system on firm value is not statistically significant. The coefficients for the control variables show that size, leverage, quick ratio, and investment opportunities affect the firm value. Similar to the first period, the ROA and financial constraints are not statistically significant. In order to overcome endogeneity concerns, firm fixed-effects panel data models were estimated. Furthermore, in unreported robustness tests, the models have been estimated as an instrumental variables panel model with firm fixed-effects and it has been found that the results are robust to the inclusion of firm fixedeffects.

Table 5

The Effect of ERM Adoption on Firm Value (2001-2011)

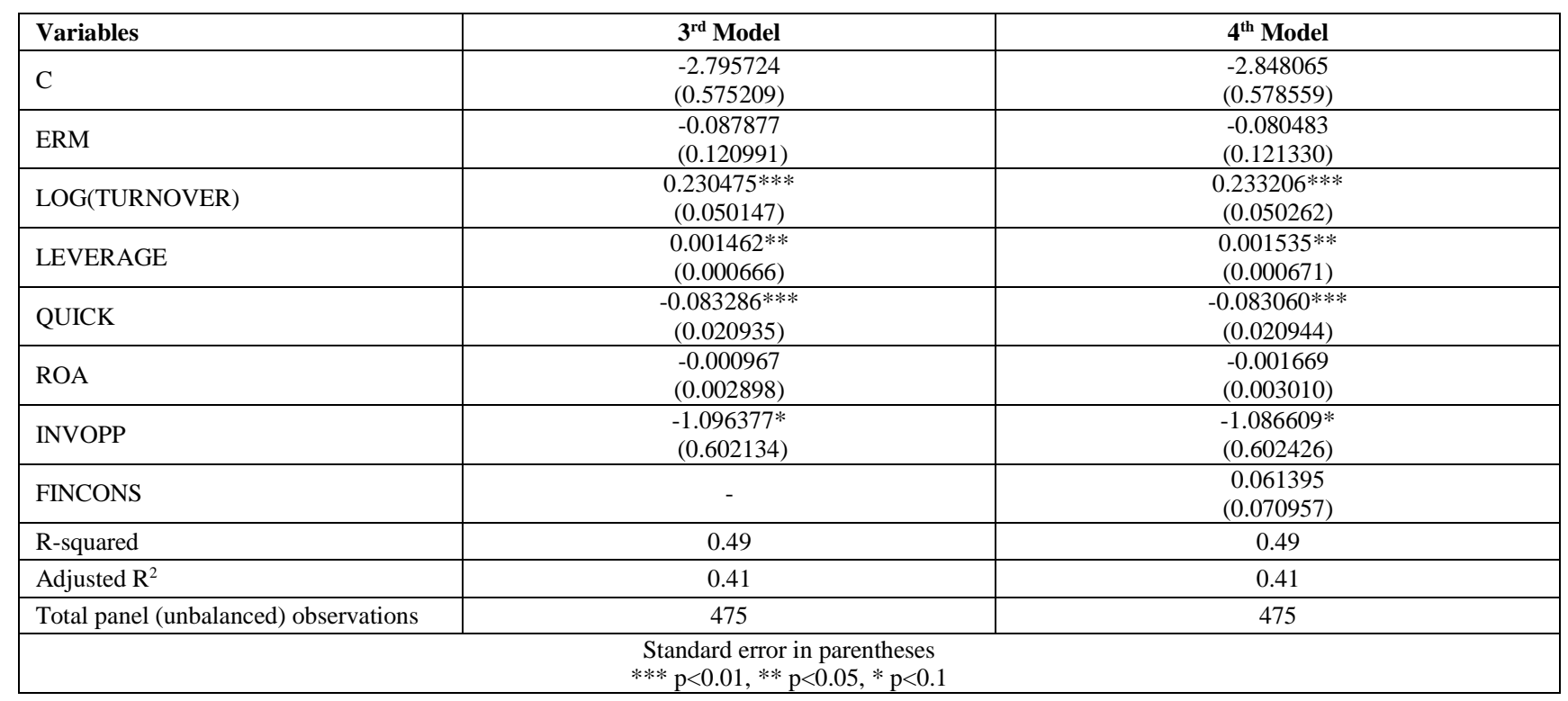


The results of this research have implications for policy makers, practitioners, and academics. These findings lend support for the recent pressure on firms to adopt more integrated and comprehensive risk management systems. The contributions to the analysis of risk management decisions for emerging markets firms consist in testing the relationship between ERM and firm value based on a sample of public firms from Romania.

\section{Conclusions and Further Research}

An increasing number of Romanian firms have either implemented or are considering the adoption of ERM programs. In the extant literature focusing on emerging markets, there is not much empirical evidence on whether and how such programs affect firm value. Moreover, the majority of the empirical studies concern the financial industry, in particular, the insurance one. The main reason behind this lack of research on the value relevance of ERM is that the firms do not have to report information about the adoption of ERM framework. Also, the lack of an effective proxy for ERM adoption hampered the evolution of research on the relationship between ERM and firm value.

Using a hand-collected data set containing information about Romanian non-financial firms listed on Bucharest Stock Exchange over the period 2001-2011, this paper aim to investigate the effects of ERM implementation on the firm value. The results of panel data model with fixedeffects suggest that, on this particular sample of Romanian public firms before the onset of global financial crisis (2001 -2007), ERM creates value, after controlling for variables known to be associated with both higher values and decisions to implement ERM. Non-financial firms using ERM are valued as much as $46.5 \%$ higher than other firms. The results show that the ERM premium is statistically and economically significant. These findings are broadly in line with those reported by other studies on samples of firms from developed economies and provide empirical evidence for the recent initiatives to adopt ERM. On the other hand, over periods of economic and financial turbulences, the ERM does not affect firm value in any significant manner.

The paper contributes to the financial literature through the expansion of the research concerning the relationship between ERM and firm value in an under-investigated context such as emerging economies. However, there are two important limits of this analysis. Firstly, the relatively small sample size may influence the extent to which these findings may be generalized to all emerging markets. Secondly, this study does not take into consideration how the framework was implemented by the organization's leadership and employees. Further research using a larger sample of firms from more emerging economies, employing new proxies that take into account the complex nature of ERM (e.g., an index for ERM sophistication) or assessing the ways in which ERM contributes to firm value could bring new contributions to the growing empirical research on ERM.

\section{Acknowledgements}

The author would like to thank Alin Andries and Sebastian Lazar for their comments on earlier drafts of the paper.

\section{References}

Allayannis, G., \& Weston, J. P. (2001). The use of foreign currency derivatives and firm value. The Review of Financial Studies, 14, 243-276. https://doi.org/10.1093/rfs/14.1.243

Allayannis, G., Lel, U., \& Miller, D. P. (2012). The use of foreign currency derivatives, corporate governance, and firm value around the world. Journal of International Economics, 87(1), 65-79. https://doi.org/10.1016/j.jinteco. 2011.12.003

Aretz, K., Bartram, S. M., \& Dufey, G. (2007). Why hedge? Rationales for corporate hedging and value implications. Journal of Risk Finance, 8(5), 434-449. https://doi.org/10.1016/j.jinteco.2011.12.003

Bartram, S. M., Brown, G. W., \& Conrad, J. (2011). The effects of derivatives on firm risk and value. Journal of Financial and Quantitative Analysis, 46(4), 967-999. https://doi.org/10.1017/S0022109011000275

Baxter, R., Bedard, J. C., Hoitash, R., \& Yezegel, A. (2013). Enterprise risk management program quality: Determinants, value relevance, and the financial crisis. Contemporary Accounting Research, 30, 1264-1295. https://doi.org/10.1111/j. 1911-3846.2012.01194.x

Beasley, M. S., Pagach, D., \& Warr, R. (2008). Information conveyed in hiring announcements of senior executives overseeing enterprise-wide risk management processes. Journal of Accounting, Auditing and Finance, 23(3), 311-332. https://doi.org/10.1177/0148558X0802300303

Belghitar, Y., Clark, E., \& Salma, M. (2013). Foreign currency derivative use and shareholder value. International Review of Financial Analysis, 29, 283-293. https://doi.org/10.1016/j.irfa.2012.02.004

Bertinetti, G. S., Cavezzali, E., \& Gardenal, G. (2013). The Effect of the Enterprise Risk Management Implementation on the Firm Value of European Companies. Working Paper No. 10, Università Ca' Foscari Venezia, Italy. http://virgo.unive.it/wpideas/storage/2013wp10.pdf.

Bessembinder, H. (1991). Forward contracts and firm value: investment incentive and contracting effects. Journal of Financial and Quantitative Analysis, 26, 519-532. https://doi.org/10.2307/2331409

Carter, D. A., Rogers, D. A., \& Simkins, B. J. (2006). Does hedging affect firm value? Evidence from the US airline industry. Financial Management, 35, 53-86. https://doi.org/10.1111/j.1755-053X.2006.tb00131.x 
Colquitt, L. L., Hoyt, R. E., \& Lee, R. B. (1999). Integrated risk management and the role of the risk manager. Risk Management and Insurance Review, 2(3), 43-61. https://doi.org/10.1111/j.1540-6296.1999.tb00003.x

Eckles, D. I., Hoyt, R. E., \& Miller, S. M. (2014). The impact of enterprise risk management on the marginal cost of reducing risk: Evidence from the insurance industry. Journal of Banking and Finance, 43, 247-261. https://doi.org/10.1 016/j.jbankfin.2014.02.007

Farrell, M., \& Gallagher, R. (2015). The Valuation Implications of Enterprise Risk Management Maturity. Journal Risk and Insurance, 82(3), 625-657. https://doi.org/10.1111/jori.12035

Fauver, L., \& Naranjo, A. (2010). Derivative usage and firm value: The influence of agency costs and monitoring problems. Journal of Corporate Finance, 16(5), 719-735. https://doi.org/10.1016/j.jcorpfin.2010.09.001

Froot, K., \& Stein, J. (1998). Risk management, capital budgeting, and capital structure policy for financial institutions: An integrated approach. Journal of Financial Economics, 47, 55-82. https://doi.org/10.1016/S0304-405X(97)00037-8

Gordon, L. A., Loeb, M. P., \& Tseng, C. Y. (2009). Enterprise risk management and firm performance: A contingency perspective. Journal of Accounting and Public Policy, 28 (4), 301-327. https://doi.org/10.1016/j.jaccpu bpol.2009.06.006

Grace, M. F., Leverty, J. T., Phillips, R. D., \& Shimpi, P. (2015). The value of investing in enterprise risk management. The Journal of Risk and Insurance, 82(2), 289-316. https://doi.org/10.1111/jori.12022

Guay, W., \& Kothari, S. P. (2003). How much do firms hedge with derivatives?. Journal of Financial Economics, 80, 423461. https://doi.org/10.1016/S0304-405X(03)00179-X

Harrington, S. E., Niehaus, G., \& Risko, K. J. (2002). Enterprise Risk Management: The Case of United Grain Growers. Journal of Applied Corporate Finance, 14(4), 71-81. doi:10.1111/j.1745-6622.2002.tb00450.x.

Hoyt, R., \& Liebenberg, A. (2011). The value of enterprise risk management. Journal of Risk and Insurance, 78(4), 795822. https://doi.org/10.1111/j.1539-6975.2011.01413.x

Hoyt, R., \& Liebenberg, A. (2015). Evidence of the value of enterprise risk management. Journal of Applied Corporate Finance, 27(1), 41-47. doi: 10.1111/jacf.12103.

Jin, Y., \& Jorion, P. (2006). Firm value and hedging: Evidence from U.S. oil and gas producers. The Journal of Finance, 61, 893-919. https://doi.org/10.1111/j.1540-6261.2006.00858.x

Lundqvist, S. A. (2015). Why firms implement risk governance - Stepping beyond traditional risk management to enterprise risk management. Journal of Accounting and Public Policy, 34(5), 441-466. https://doi.org/10.1016/j. jaccpubpol.2015.05.002

Li, Q., Wu, Y., Ojiako, U., Marshall, A., \& Chipulu, M. (2014). Enterprise risk management and firm value within China's insurance industry. Acta Commercii, 14(1), 1-10. https://doi.org/10.4102/ac.v14i1.198

Li, Z., Wang, Y., Yu, L., \& An, H. (2016). Relationship between initiative risk management and firm value: evidence from Chinese financial listed companies. Applied Economics, 48(8), 658-668. https://doi.org/10.1080/000368 46.2015.1085639

McShane, M., Nair, A., \& Rustambekov, E. (2011). Does enterprise risk management increase firm value?. Journal of Accounting. Auditing and Finance, 26(4), 641-658. https://doi.org/10.1177/0148558X11409160

Milos Sprcic, D., Mesin Zagar, M., Sevic, Z., \& Marc, M. (2016). Does enterprise risk management influence market value - A long-term perspective. Risk Management, 18 (2/3), 18-65. https://doi.org/10.1057/rm.2016.3

Modigliani, F., \& Miller, M. H. (1958). The cost of capital, corporation finance and the theory of investment. American Economic Review, 48(3), 261-297.

Nance, D. R., Smith Jr., C. W., \& Smithson, C. W. (1993). On the determinants of corporate hedging. Journal of Finance, 48, 267-284. https://doi.org/10.1111/j.1540-6261.1993.tb04709.x

Nelson, J., Moffitt, J. S., \& Affleck-Graves, J. (2005). The impact of hedging on the market value of equity. Journal of Corporate Finance, 11, 851-881. https://doi.org/10.1016/j.jcorpfin.2005.02.003

Nocco, B., \& Stulz, R. (2006). Enterprise risk management: Theory and practice. Journal of Applied Corporate Finance, 18(4), 8-20. https://doi.org/10.1111/j.1745-6622.2006.00106.x

Panaretou, A. (2014). Corporate Risk Management and Firm Value: Evidence from the UK Market. The European Journal of Finance, 20(12), 1161-1186. https://doi.org/10.1080/1351847X.2013.766625

Pagach, D. P., \& Warr, R. S. (2010). The effects of enterprise risk management on firm performance. Working Paper, Social Science Research Network. Available at SSRN http://ssrn.com/abstract=1155218.

Smith, C. W., \& Stulz, R. (1985). The determinants of firms' hedging policies. Journal of Financial and Quantitative Analysis, 20(14), 391-405. https://doi.org/10.2307/2330757

The article has been reviewed.

Received in October, 2016; accepted in March 2018. 